\title{
'JUGGLING THE GLASS BALLS ...': WORKPLACE SPIRITUALITY IN WOMEN LEADERS
}

\author{
C-H. Mayer \\ Department of Management \\ Rhodes University, Grahamstown, South Africa \\ Institut für Therapeutische Kommunikation \\ Europa-Universität Viadrina, Frankfurt (Oder), Germany \\ e-mail: claudemayer@gmx.net
}

\section{R. Viviers* \\ e-mail: rianviv@gmail.com}

\section{R. Oosthuizen*}

e-mail: oosthrm@unisa.ac.za

\section{S. Surtee}

HERS-SA

Cape Town, South Africa

e-mail: director@hers-sa.org.za

*Department of Industrial and Organisational Psychology

University of South Africa

Pretoria, South Africa

\section{ABSTRACT}

This qualitative study explored workplace spirituality in women leadership in higher education institutions (HEIs). Interviews were conducted with women leaders of the Higher Education Research Service network across eight institutions. Observations were made in one organisation. Findings show that women leaders are highly aware of their spirituality and religious affiliation which influence their work and work spirituality. Workplace spirituality includes how women leaders approach life and work, how spirituality expands their concept of religion and how the interwoven concepts of spirituality and religion help them to manage their work optimally. The study was limited to a relatively small sample size of 23 women leaders and was further bound to the qualitative research methodology. This study provides valuable insights into workplace spirituality regarding women leaders in South African HEls. The findings provide a base for future research on women leaders in organisations and for leadership training of women within HEIs.

Keywords: spirituality, women leaders, higher education institutions, South Africa 


\section{INTRODUCTION}

Spirituality has established itself as a well-recognised and researched element of physical and mental health and psychological wellbeing (Banks and Lee 2016; Delle Fave et al. 2013; Steffen 2012; Steger 2012; Wissing et al. 2014). Since the formal acknowledgement of positive psychology as an emerging field within psychology in 2000 (Peterson and Seligman 2004; Snyder and Lopez 2002), spirituality has more frequently been associated with health and personal wellbeing. It is regarded as a character strength and virtue (Peterson and Seligman 2004) and is often referred to in its broader sense, including synonyms such as religiousness, faith or purpose. In this article the term 'spirituality' will be used in its broader context.

Spirituality could be regarded as a holistic life concept (Mayer 2012) of an individual in search of the sacred and as a person's connection to God, or any god-like entity, or transcendent being which is regarded as a higher power (Knoblauch 2006). Spirituality is often strongly connected to religion, but is not necessarily tied to religion or the active practice of a religion (Baker 2003; Lehtinen et al. 2005). For the purpose of this article, spirituality is viewed as a 'deep, intuitive feeling of connectedness' to the sacred in a dynamic and changing world (Eckersley 2007, 220).

In general life, spirituality is often regarded as an enabling factor for an individual to develop a positive mindset and inner peace (Koenig, McCullough and Larson 2001; Underwood and Teresi 2002), but also wholeness (Rozario 1997) which could eventually lead to a healthy mental state, happiness and flourishing (Wissing et al. 2014). The pursuit of the sacred is therefore an individual's inner striving to engage in positive attitudes and relationships throughout life (Van Dierendonck and Mohan 2006).

\section{WORKPLACE SPIRITUALITY}

Spirituality in the workplace has not been taken seriously in the past (Amin Mohamed et al. 2004; Butts 1999; Hall, Dixon and Mauzey 2004; Sheep 2004) and was neglected as an important aspect that could impact employees (Pawar and Pawar 2016). This trend, however, is rapidly changing and more scientific studies have emerged to explore workplace spirituality (WSP) as an important factor in the work context (Houghton, Neck and Krishnakumar 2016; Madden 2015; Sandhu 2016; Shahabinasab et al. 2016). WSP has been directly linked to a variety of organisational factors, such as organisational citizenship (Shahabinasab et al. 2016), employee wellbeing and job satisfaction (Bell 2016), employee satisfaction (Sandhu 2016), emotional exhaustion and work-related family issues (Liang, Liang and Sun 2016), organisational politics (Khatri and Gupta 2016), management (Tzouramani and Karakas 2016), 
responsible leadership (Kempster and Carroll 2016), career development (Bloch and Richmond 2016) and also work-life balance (Stoltz-Loike 2016).

Spiritual practice could entail extrinsic religiousness (Khumalo 2014; Van Dierendonck and Mohan 2006) - the use of religion to provide security, comfort, status and/or social support. In the work domain extrinsic religiousness could be used for utilitarian and/or external motives (Khumalo 2014) as spirituality becomes a functional means in the workplace (Steger and Frazier 2005). Bloch and Richmond (2016) firmly believe that meaning in the postmodern workplace could be obtained through the exploration of the connectedness between spirit and career. Lee, Lovelace and Manz (2014) specifically point out the positive impact of WSP on employees' emotional states at work.

More liberal organisations have recently started facilitating and promoting the important role of WSP (Porter and Norris 2013) as it enables more productive and positive work practices (Paul, Dutta and Saha 2016; Petchsawang and Duchon 2012) and also more positive workplace practices. According to these findings, Miller and Ewest (2013) are of the opinion that diverse religious traditions should therefore be accommodated and explored so as to determine the impact of individual or collective spirituality in the workplace.

\section{WORKPLACE SPIRITUALITY IN WOMEN LEADERS}

Women leaders in the world of business are often discriminated against and could face social and economic penalties for behaving counter-stereotypically (Rudman et al. 2012). They found in a series of five studies that women are proscribed from dominant, high status positions (traditionally reserved for men); that prejudice against agentic female leaders was mediated by a dominance penalty; that participants' gender system-justifying beliefs moderated backlash effects; that backlash was exacerbated when perceivers were primed with a system threat; and finally, that only female leaders who threatened the status quo suffered sabotage.

This 'traditional' discrimination of women leaders' experience might be alleviated by the intervening effects of personal resources they apply to help them cope in the brutal leadership context (Bakker and Xanthopoulou 2013). Women leaders not only need to excel in managerial and leadership positions once they manage to reach that cadre, but also need to maintain family life and often struggle with a work-life balance (Tomer et al. 2015). In order to 'juggle the balls', they often rely on their religious beliefs to help them cope in daily life (Mayer and Surtee 2015; Mayer, Surtee and May 2015; Reid, Roumpi and O'Leary-Kelly 2015). Paul et al. (2016) found that workplace spirituality helped to maintain a work-life balance among women executives of IT sector companies in India. Reid et al. (2015) found that in Ghana female 
entrepreneurs tended to invoke spirituality in the context of personal and work-related challenges. Ngunjiri (2016) indicates that spirituality enabled women leaders are stronger and courageous when facing difficult circumstances, as it provides them with a sense of purpose and strengthens their calling for their work, which further enables them to be more effective servant leaders.

The previous examples all relate to being stronger and more effective in the work context. Person, May and Mayer (2016) add to the above by introducing the concept of meaningfulness of work experiences by women leaders through spirituality at work. They are of the opinion that meaningfulness is based on the concepts of inner-connectedness and trans-personality, which plays out as a coping resource in the work context (Mayer and Surtee 2015; Mayer et al. 2015). The purpose of this study was to explore, from a qualitative research perspective, workplace spirituality in women leadership in higher education institutions (HEIs).

\section{METHOD}

To date, there appears to be no hermeneutic phenomenological research on workplace spirituality in women leadership in South African HEIs. Utilising the theoretical principles and practices of hermeneutic phenomenology, this study aimed to gain access to a phenomenon that is often subconscious in order to understand the nature and meaning of the participants' lived experiences. The interpretation of the texts of life was expected to yield rich and detailed descriptions of workplace spirituality in women leadership in South African HEIs (Chan, Walker and Gleaves 2015; Creswell 2015; Fossey et al. 2002). The concept of Dilthey's modern hermeneutics (2002) was used to create 'Verstehen' (understanding) of workplace spirituality in women leadership in HEIs. To construct, analyse and interpret the data, researchers used a self-reflective attitude as described by Ratner (2002).

\section{Sample}

In accordance with the interpretive research paradigm, and in line with the need to explore participants experiencing the phenomenon under inquiry, snowball sampling strategies were used to select the participants (Denzin and Lincoln 2000; Woodley and Lockard 2016). Women leaders were invited to participate in the research project through their membership of HERSSA (Higher Education Resource Services South Africa). HERS-SA is a non-profit South African organisation which offers professional and leadership development and training to women leaders in HEIs. A total of 900 women were invited, but only 29 women from eight HEIs participated. Qualitative interviews covered issues such as women's leadership challenges 
and workplace spirituality in HEIs.

\section{Data collection}

Data were collected through semi-structured interviews. Interviews were conducted either via Skype or as face-to-face interactions (30-60 minutes each) in English. The interview questions were based on an extensive literature review on gender discrimination in leadership positions in South African organisations (Mayer and Barnard 2015; Mayer and Van Zyl 2013; Mayer, Surtee and May 2015). The interviews were recorded and transcribed verbatim. Observations in HEIs were captured in field notes and used for the interpretation of interview data (Graham and Bell 2016; Walsh, Fleming and Enz 2016).

\section{Data analysis and interpretation}

As this was an interpretive hermeneutic phenomenological study, the analysis and interpretation of the interviews were guided by Van Manen's methodical procedures (2007). Interview data was analysed through the five-step process of content analysis: step 1 - familiarisation and immersion; step 2 - inducing themes; step 3 - coding; step 4 - elaboration; and step 5 interpretation and checking (Terre Blanche, Durrheim and Kelly 2006, 322-326; Vaismoradi et al. 2016). Data gathered through observation at one selected HEI contributed to a deeper understanding, analysis and interpretation of data (Yin 2009) of workplace spirituality in women leadership in HEIs.

\section{QUALITATIVE RESEARCH CRITERIA}

Qualitative research criteria included the definition of the 'worthy topic', rich rigor, sincerity, credibility, resonance, the significant contribution, ethics and the meaningful coherence (Tracy 2010). Data quality was further ensured through informed consent, anonymity, rigorous analysis and constant comparison of the data and of the research topic throughout the analysis (Charmaz 2011). Participants voluntarily participated in the study. Inter-subjective validation processes were conducted amongst the researchers throughout the research study through discussions and common reflections (Yin 2009).

\section{Ethical considerations}

Research ethics were applied throughout the research process, including assuring informed consent, anonymity, confidentiality and the freedom to withdraw from the interview process at any time. Ethical approval was given by the Ethics Research Committee at Rhodes University, Grahamstown, SA and HERS-SA. 


\section{FINDINGS}

All of the 29 participants responded to the questions on what spirituality meant to them and how it impacted on them and their work. Although the questions were related to spirituality only, several interviewees commented on spirituality and religion; some responses were intertwined without a clear distinction between the differences and/or with explicit explanations of how these two concepts are related in the opinion of the interviewees. With regard to religious affiliation, interviewees referred to their religious affiliation and their spirituality, as shown in Table 1.

Table 1: Religious affiliation and general approach to spirituality

\begin{tabular}{|c|c|c|c|}
\hline $\begin{array}{l}\text { Self- } \\
\text { defined } \\
\text { race }\end{array}$ & Interview number & Religious affiliation & Comment on spirituality \\
\hline Indian & $19, I 17, I 18,122$ & Hindu & $\begin{array}{l}\text { Spirituality is very important and } \\
\text { plays a major role in life and } \\
\text { work. }\end{array}$ \\
\hline Black & B12, B21, B29 & Christian & $\begin{array}{l}\text { Spirituality is very important and } \\
\text { plays a major role in life and } \\
\text { work. }\end{array}$ \\
\hline White & $\begin{array}{ll}\text { - } & \text { W3, W16, W27 } \\
\text { - } & \text { W15 } \\
\text { - } & \text { W10, B29 } \\
\text { - } & \text { W2, W25 } \\
\text { - } & \text { W6, W10, W15 } \\
\text { - } & \text { W25 } \\
\text { - } & \text { W26, W2 }\end{array}$ & $\begin{array}{ll}\text { - } & \text { Atheist } \\
\text { - } & \text { Protestant } \\
\text { - } & \text { Roman Catholic } \\
\text { - } & \text { Interfaith } \\
\text { - } & \text { Christian } \\
\text { - } & \text { Spiritual } \\
\text { - } & \text { Buddhist }\end{array}$ & $\begin{array}{ll}\text { - } & \text { Not spiritual } \\
\text { - } & \text { Spiritual } \\
\text { - } & \text { Spiritual } \\
\text { - } & \text { Spiritual } \\
\text { - } & \text { Spiritual } \\
\text { - } & \text { Spiritual } \\
\text { - } & \text { Spiritual }\end{array}$ \\
\hline Coloured & $\mathrm{C} 8, \mathrm{C} 13, \mathrm{C} 19, \mathrm{C} 23, \mathrm{C} 28$ & Christian & $\begin{array}{l}\text { Spirituality is very important and } \\
\text { plays a major role in life and } \\
\text { work. }\end{array}$ \\
\hline
\end{tabular}

Table 1 shows that for Indian, black and coloured women, their religious affiliation were clearly connected to spirituality. For them, spirituality was often interwoven with religion, supporting each other mutually: spirituality contributes to religion and religion contributes to spirituality. One black Christian woman leader highlighted, for example, (B21):

For me it (spirituality/religion) is basically my relationship with God - the way I see God and spirituality in the workplace is how I live out my spiritual aspect.

An Indian Hindu interviewee contributed the following (I9):

All depends on what religion ... In the Eastern philosophies if you believe in a form of God, you look at male and female. It's also the feminine aspects, and for us the feminine aspect is more important than the male aspect.

A coloured Christian woman leader pointed out (C8) that her belief in being a Christian was strongly connected to her spirituality, her values and her integrity as a woman leader. She felt 
that her work was part of her calling and a core to fulfil it:

Well I suppose my feet are firmly grounded in the fact that I'm a Christian. For me that directs a lot of my life calling, I suppose. So from that perspective, for instance it's quite important for me to act with integrity, because if I didn't, it would be compromising my entire value system, my spiritual belief. I hold to Christian values and I believe I'm called for the work that I do; so for me that is a very important aspect of my work.

For white interviewees, the connection and interrelationship of religion and spirituality emerged in various ways. Two of the white interviewees were Buddhists and their spirituality was interwoven with their religious affiliation and their views supported each other. The other white interviewees commented on their religion - without even being asked to do so - in different ways: three of them highlighted that they were born Christian, but turned to atheism for either unmentioned or other reasons (W27) regarding struggles with Christianity (W16, W27).

One Christian woman commented on Protestant work ethics; two mentioned their background as being Christian (W10, B21) and another (W10) converting from Anglican to Catholicism within a two-year period. Two women believed in interfaith dialogue, and one said that being Christian was 'being spiritual' (W25). One woman pointed out that Christianity was important to her as an overall religious affiliation (W6), whilst two said that Christianity and their particular denomination were both important (W10, W15).

\section{Concepts of spirituality}

The concept of spirituality is connected to four themes. The overviews of several categories are provided in Tables 2 to 5. The following themes are explored: Approach to life and work, values, expanding religion, and spirituality as a resource.

\section{Approach to life and work}

For most of the interviewees, spirituality was an approach to life and to work: it was about core beliefs, the understanding of the world and life centeredness around God (12 statements each). Spirituality was also believed to be an identity-building concept (8 statements) and it was about how a person lived their life and how they worked; it was about inner balance (6 statements each) and about seeing life and development as a journey (3 statements).

A coloured female leader referred to the interconnectedness of spirituality as a core belief. For her, spirituality was her faith and lifestyle by believing in a higher force (C28):

For me, spirituality is the way in which I practise my faith, but it is also beyond that. It's again the relational aspect. It's relationship with who one regards as your higher being, and how that higher being, whether you call it God, or Allah or Buddha or whatever, how that relationship impacts on 
your life. And it's not just a relationship with a higher force, but also a relationship with the earth and the world, with all living beings. For me that's the essential aspect of spirituality. And in the workplace, it is how one relates to each other because you regard others as being the incarnation of a higher being.

Table 2: Concepts of spirituality: Approach to life and work

\begin{tabular}{|l|l|l|l|}
\hline $\begin{array}{l}\text { Theme } \\
\text { concept of } \\
\text { spirituality }\end{array}$ & Category & Interview numbers & Total \\
\hline Approach to life & Core belief & $\begin{array}{l}\text { I18, I22, W2, W3, W27, W16; W15, W7; } \\
\text { C28, C8, B21, B29 }\end{array}$ & 12 \\
\hline & Understanding the world & $\begin{array}{l}\text { B12, B29, C8, I22, I18, 19, W26, W16, } \\
\text { W15, W7, C28, C23 }\end{array}$ & 12 \\
\hline & C19, W6, W14, W3, W25, B12, B21, B29 & 8 \\
\hline & Identity & B12, C19, C23, W15, W16, W7 & 6 \\
\hline & $\begin{array}{l}\text { How you live your life and } \\
\text { work }\end{array}$ & C8, W10, W25, I18, 19, I22 & 6 \\
\hline & Inner balance & B21, W6, W15 & 3 \\
\hline Total & A journey & & $\mathbf{5 9}$ \\
\hline
\end{tabular}

For eight individuals, spirituality was a core identity aspect as it provided women leaders with ideas on how to live their lives and how to conduct their work in terms of ethics and religion (6 statements). Women leaders felt that spirituality provided them with inner balance (6 statements). Three women saw life as a journey and spirituality as one of the dynamic aspects in life that accompanied and guided them, whilst spirituality was a journey in itself and therefore developmental. W6 emphasised:

Spirituality is huge to me. I'm a Christian and I'm certainly on a very long journey, I have a heck of a long way to go, but I can't manage without being spiritual. To me spirituality believes in a higher Being. And for me it's believing there is a God and I'm being guided on my journey. And I have to trust and believe that the journey I'm being taken on is right for me. That to me is my spirituality.

For this woman leader, spirituality formed the core of her journey and was part of her daily leadership practices. It was a complex concept which was connected to a higher being and being guided by her actions. As seen in her statement, spirituality and the practice of her Christian religion were strongly interlinked.

\section{Values}

The women leaders emphasised that values were very important in terms of spirituality. For them, spirituality spoke of 'respect for humanity' (7 statements) and included compassion and kindness, ethical attitudes and behaviour (5 statements each) and the freedom of belief (4 statements), and was connected to core values, such as honesty (3 statements) and sharing (2 statements).

Several interviewees talked about the importance of respect for humanity and this core 
value of life and work as a basis of spirituality. One white woman (W5) felt that spirituality connected her with others, particularly in times of crisis, and gave her respect for others. W26 supported this: 'Spirituality relates to the respect for humanity. It provides you with understanding, a broader view on things and respect.'

For five individuals, spirituality was connected to compassion, kindness and ethics. I18, an Indian SA woman leader, regarded the connection of spirituality as a container for core values and a kind, compassionate attitude:

To me spirituality means values. There are good values and bad values ... so spirituality in the workplace means good values, but that's something that has to be talked about and negotiated.

Spirituality was a leadership attribute based on (spiritual) values to support compassionate, respectful and kind behaviour in leaders and in organisations. This leader argued that spirituality needed to be talked about and negotiated as it provided individuals with core values and attitudes. W20 highlighted that spirituality guided ethical behaviour directly:

... I talk about the ethical aspects of what I do and want to live as an ethical person, and to work well with other people and to sort of have understanding and awareness of the needs of other people around me, and I think that may be articulated in a sort of spiritual way.

For her, spirituality was directly connected to ethics and ethical leadership, which was again related to working well with others, understanding, awareness and addressing the needs of others. Spirituality was therefore a core concept of ethics.

Four white women leaders indicated the importance of freedom of belief. In their opinion, spirituality provided the right to anyone of freedom of thought and religion, as they felt that spirituality did not have an institutional base. This was important to these white women leaders, based on their experiences as Christians, highlighting that religions should not be exclusive and should be interpreted as being inclusive of diversity in the workplace.

Table 3: Concepts of spirituality: Values

\begin{tabular}{|l|l|l|l|}
\hline Values & Respect for humanity & $\begin{array}{l}\text { B21, B12, W5, W16, C23, I17, I18, } \\
\text { W26 }\end{array}$ & 7 \\
\hline & Compassion/kindness & I9, I18, C13, W26, W6 & 5 \\
\hline & Ethical attitude \& behaviour (ethics) & W2, W20, W3, W15, W25, & 5 \\
\hline & Freedom of belief & W2, W5, W16, W15 & 4 \\
\hline & Honesty & W3, I18, W26 & 3 \\
\hline & Sharing & C23, W26 & 2 \\
\hline Total & & & $\mathbf{2 6}$ \\
\hline
\end{tabular}

\section{Expanding religion}

The theme of expanding religion is based mainly on the categories 'consciousness/ 
mindfulness/awareness' (8 statements), 'more than religion' and 'commonness of religions' (6 statements each), and 'interfaith dialogue' (3 statements). WSP was seen as an aid that helped individuals to be conscious, mindful and aware in the workplace. A white Buddhist woman provided her views on spiritual leadership (W25):

To me it is very much related to awareness and consciousness, and living in the moment in what I'm doing. If I'm working, it means that I'm completely in that particular vein, not with my mind being all over the place. I'm completely focused on being in that zone.

Spirituality provided her with awareness, consciousness and a certain kind of flow and focus which made her live in the moment, working completely focused, applying herself as a whole person, with contained and focused energy. Spirituality seemed to be strongly connected to flow, presence and focus as an inner attitude.

Data show that spirituality was a concept that expanded religious affiliation for six of the women interviewed. Spirituality provided them with the freedom to create a belief that was rather independent of an institutional affiliation and the strict boundaries of, for example, the church. For them, religion was bound to institutional boundaries, whilst spirituality was more open and could be used as a practical application of religion on a daily basis and in leadership practices.

Several women (6 statements) highlighted that spirituality created togetherness, commonness and a feeling of connectedness. I9, for example, emphasised how spirituality helped to bridge differences at individual and racial levels:

Irrespective of whatever religion you are, I believe there's one Creator who is one God and I believe we are all part and parcel of that, we just, well, whatever colour, or hairstyles we use, we are all part of his creation. So I try to be as fair as possible to all concerned, but we do have an abnormal society that translates into the workplace, and I try to keep a balance with the spiritual part of it.

For her, spirituality provided a possibility to contain the societal abnormalities which spill over in the workplace. It provided her with an alternative perspective, a resource for strength and inner balance in a racially divided world. Spirituality helped her to focus on the inside, on the internal. It was therefore a space that moved the focus from difference, racial divide and marginalisation to an inner, safe space where she tried to balance herself and her experiences in society and the workplace. WPS also seemed to support and create space for 'interfaith dialogue', an important aspect in a workplace based on diversity. W2 pointed out:

Spirituality means letting people believe what they want in terms of their own spirituality. I'm a great fan of interfaith dialogue. 
This statement shows the interlinked nature of freedom of belief and how employees use spirituality to reach out, 'cross the boundaries' and connect through WPS. This participant revealed how people use spirituality to connect to others in bridging differences, by creating commonalities and similarities. For her, spirituality was important not only at a micro-level, but also at an organisational and a global level.

Table 4: Concepts of spirituality: Expanding religion

\begin{tabular}{|l|l|l|l|}
\hline $\begin{array}{l}\text { Expanding } \\
\text { religion }\end{array}$ & $\begin{array}{l}\text { Consciousness/ } \\
\text { mindfulness/awareness }\end{array}$ & $\begin{array}{l}\text { W15, W16, W20, W11, I18, C23, } \\
\text { C28, C8 }\end{array}$ & 8 \\
\hline & More than religion & B29, I22, W5, W11, W6, W14 & 6 \\
\hline & $\begin{array}{l}\text { Spirituality is what religions } \\
\text { have in common }\end{array}$ & I18, B29, C19, W5, W14, C28 & 6 \\
\hline & Interfaith dialogue & W2, W7, W25 & 3 \\
\hline Total & & & $\mathbf{1 6}$ \\
\hline
\end{tabular}

\section{Spirituality as a resource}

Fourteen statements reflect spirituality as being a resource in life and at work for women leaders. The women surveyed found spirituality to be a way to cope with challenges (6 statements), a kind of 'opener', providing them with information or an 'open heart' to look beyond their situation, themselves or the context (5 statements). All the black women commented that spirituality was a support and help, for themselves and to support others through support groups at a collective level or an individual level (3 statements). This aspect is interesting, as most other women leaders defined spirituality in terms of an 'individual belief' (see W27) and not as a collective 'get together' to support the self and/or others.

Table 5: Concepts of spirituality: Resource

\begin{tabular}{|l|l|l|c|}
\hline Resource & Way to cope & I22, B29, C13, W6, W10, W27 & 6 \\
\hline & $\begin{array}{l}\text { Eye opener (seeing bigger } \\
\text { picture) }\end{array}$ & B12, W11, W27, W15, I22 & 5 \\
\hline & Support for self and others & B12, B21, B29 & 3 \\
\hline Total & & $\mathbf{1 4}$ \\
\hline
\end{tabular}

Several women directly or indirectly emphasised that spirituality was a powerful resource in terms of life and work. It provided a way to cope with challenges (6 statements), to open their eyes, thereby expanding their personal worldview (5 statements), the situation or the context, and so enabled them to see the 'bigger picture' behind the situation.

W10 emphasised:

It's a coping mechanism ... In the office, I have a rosary next to me, and so I am spiritual, because it helps me cope.

For W10, spirituality was connected to her religious practice of praying, as well as to her 
spiritual belief in the power of rosaries. Spirituality became a combined spiritual/religious concept which helped her cope at work. She defined spirituality functionally as a 'coping mechanism'. Spirituality became a combined individual and collective concept of support of self and others - in the sense of caring - and a strong connection with other human beings in life and in the workplace.

\section{DISCUSSION}

As discussed in the literature (Banks and Lee 2016; Delle Fave et al. 2013; Steffen 2012; Steger 2012; Wissing et al. 2014), spirituality can contribute to physical and mental health. The findings support this assumption by showing that spirituality is an important resource in the life and work of women leaders, providing a specific approach to life and work, values, expanding religious views and acting as a resource. Women leaders see spirituality as identity building, which can be compared to Peterson and Seligman's view of spirituality (2004) as a character strength and virtue. Women leaders often refer to these character strengths and virtues as values, such as respect for humanity, freedom of belief and core values, which include honesty and sharing.

Mayer (2012) and Knoblauch (2006) point out that spirituality is viewed by women leaders as a holistic life concept which includes life and work, drawing upon concepts of religiousness, faith or purpose (Peterson and Seligman 2004). Women leaders view spirituality as a concept that expands religion and can be referred to as interfaith dialogue. The findings of this study support the perspective of Koenig, McCullough and Larson (2001) and Underwood and Teresi (2002) that spirituality can develop a positive mindset and add to the feeling of connectedness and wholeness (as referred to by Eckersley 2007).

WSP is a positive resource for women leaders during their life and particularly at work. This article contributes to the studies on WSP which emphasise WSP's importance regarding employees (Amin Mohamed et al. 2004; Butts 1999; Hall, Dixon and Mauzey 2004; Pawar and Pawar 2016; Sheep 2004) and particularly women leaders. As the concept of spirituality is described in its complexity by women leaders, it can be assumed that it impacts on leadership (Kempster and Carroll 2016), career development (Bloch and Richmond 2016) and also worklife balance (Stoltz-Loike 2016), as emphasised in the literature. Due to the complexity and importance of the concept for women leaders, this study might even support the idea of Bloch and Richmond (2016) that meaning is obtained through the exploration of the connectedness between spirit and career, as well as value-based leadership.

Based on this study, spirituality can be viewed as a coping mechanism for women leaders 
in the workplace having to cope with leadership challenges, thereby supporting previous studies in this realm (Bakker and Xanthopoulou 2013; Mayer and Surtee 2015; Mayer, Surtee and May 2015; Reid, Roumpi and O'Leary-Kelly 2015).

\section{CONCLUSIONS}

The purpose of this study was to explore workplace spirituality in women leaders in HEIs. Findings show that spirituality is a highly important concept that relates to women leaders' life and work, not the least by connecting the two, but also by providing a value base for their work in HEIs and expanding their religious concept, thereby contributing to being open to individuals of different religions, and by defining and using spirituality as a resource.

\section{Recommendations for theory and practice}

Future studies should explore the concepts of spirituality by focusing more strongly on spiritual practices. Spirituality should also be considered in the context of success, meaningfulness and work relationships. Concepts of spirituality and their correspondence in male and in female leaders should furthermore be studied and compared.

On a practical note, in a racially split society such as South Africa, society needs new (and at the same time familiar) concepts of togetherness which can bridge the gap between experienced differences and support the positive forces of reconciliation of individuals across divides. Spirituality can become a new concept of 'togetherness' that connects individuals and groups across spiritual, social, religious and cultural divides.

HEIs should become aware of the extraordinary potential of spiritual and religious concepts within the workplace and the conscious and even unconscious dynamics which occur in the context of workplace spirituality in terms of team building, commitment, working together and work attitude/meaningfulness.

Finally, women leaders should (be trained to) consciously realise the potential of their spirituality. Networking across women leaders from all group memberships could be supported by open communication and an attitude of connecting on a different (human) level through spirituality.

\section{Limitations}

Methodologically, this study was limited to a qualitative hermeneutical research paradigm and to a relatively small set of participants, who were all members of the HERS-SA network. Theoretically, this article is limited to the analysis of the data set. The aim of the article was to 
gain an in-depth understanding of women leaders' perspectives in HEIs with regard to workplace spirituality. This article does not proclaim generalisations, but provides an orientation for future research and practice in the field of women leadership, not only in HEIs but also organisations worldwide.

\section{ACKNOWLEDGEMENTS}

We thank HERS-SA for commissioning this research project and all the women who participated.

\section{Declaration of interest}

The authors declare that they have no financial or personal relationship(s) that may have inappropriately influenced them in writing this article.

\section{REFERENCES}

Amin Mohamed, A., J. Wisnieski, M. Askar and I. Syed. 2004. Towards a theory of spirituality in the workplace. Competitiveness Review: An International Business Journal 14(1/2): 102-107.

Baker, D. C. 2003. Studies of the inner life: The impact of spirituality on quality of life. Quality of Life Research 12(1): 51-57.

Bakker, A. B. and D. Xanthopoulou. 2013. Creativity and charisma among female leaders: The role of resources and work engagement. The International Journal of Human Resource Management 24(14): 2760-2779.

Banks, M. E. and S. Lee. 2016. Womanism and spirituality/theology. In Womanist and mujerista psychologies: Voices of fire, acts of courage, ed. T. Bryant-Davis and L. Comas-Díaz, 123-148. Washington, DC: American Psychological Association. http://dx.doi.org/10.1037/14937-006

Bell, K. A. 2016. Spirituality in the workplace: Differences in employee well-being and job satisfaction across spiritual and secular learning institutes. Doctoral dissertation. Capella University.

Bloch, D. P. and L. J. Richmond. 2016. Connections between spirit and work in career development: New approaches and practical perspectives. New York: Routledge.

Butts, D. 1999. Spirituality at work: An overview. Journal of Organizational Change Management 12(4): 328-332.

Chan, N. N., C. Walker and A. Gleaves. 2015. An exploration of students' lived experiences of using smartphones in diverse learning contexts using a hermeneutic phenomenological approach. Computers and Education 82: 96-106.

Charmaz, K. 2011. A constructivist grounded theory analysis. In Five ways of doing qualitative analysis, ed. F. J. Wertz, K. Charmaz, L. M. McMullen, R. Josselson, R. Anderson and E. McSpadden, 165-204. New York: The Guilford Press.

Creswell, J. W. 2015. Essential skills for the qualitative researcher. Thousand Oaks: Sage.

Delle Fave, A., M. P. Wissing, I. Brdar, D. Vella-Brodrick and T. Freire. 2013. Cross-cultural perceptions of meaning and goals in adulthood: Their roots and relations with happiness. In The best within us: Positive psychology perspectives on eudaimonic functioning, ed. A. Waterman, 227-247. Washington, DC: American Psychological Association.

Denzin, N. K. and Y. S. Lincoln. 2000. Handbook of qualitative research. 2nd edition. Thousand Oaks: Sage. 
Dilthey, W. 2002. The formation of the historical world in the human sciences. In Wilhelm Dilthey selected works. Volume III, 416-431. Princeton, NJ: Princeton University Press.

Eckersley, R. 2007. The health and wellbeing of young Australians: Present patterns and future challenges. International Journal of Adolescent Medicine and Health 19(3): 217-227.

Fossey, E., C. Harvey, F. McDermott and L. Davidson. 2002. Understanding and evaluating qualitative research. Australian and New Zealand Journal of Psychiatry 36: 717-732.

Graham, C. and A. Bell. 2016. The career advancement experiences of female faculty of color in athletic training education programs. Kansas State University Libraries: New Prairie Press. Adult Education Research Conference, 2016 Conference Proceedings. http://newprairiepress.org/ cgi/viewcontent.cgi ?article $=1005 \&$ context $=$ aerc

Hall, C. R., W. A. Dixon and E. D. Mauzey. 2004. Spirituality and religion: Implications for counselors. Journal of Counseling and Development 82(4): 504-507.

Houghton, J. D., C. P. Neck and S. Krishnakumar. 2016. The what, why, and how of spirituality in the workplace revisited: A 14-year update and extension. Journal of Management, Spirituality \& Religion: 1-29.

Kempster, S. and B. Carroll. 2016. Responsible leadership: Realism and romanticism. New York: Routledge.

Khatri, P. and P. Gupta. 2016. A study of relationship of perceived organizational politics and spirituality at workplace in IT and ITES organizations. Global Journal of Enterprise Information System 8(2): $1-8$.

Khumalo, I. P. 2014. Positive relationships: I and the great mystery. In Towards flourishing: Contextualising positive psychology, ed. M. Wissing, J. Potgieter, T. Guse, T. Khulamo and L. Nel, 207-219. Pretoria: Van Schaick.

Knoblauch, H. 2006. Soziologie der Spiritualität. In Handbuch Spiritualität: Zugänge, Traditionen, interreligiöse Prozesse, ed. K. Baier, 91-111. Darmstadt: Wissenschaftl.

Koenig, H., M. McCullough and D. Larson. 2001. Handbook of religion and health. New York: Oxford University Press.

Lee, S., K. J. Lovelace and C. C. Manz. 2014. Serving with spirit: An integrative model of workplace spirituality within service organizations. Journal of Management, Spirituality \& Religion 11(1): 45-64.

Lehtinen, V., A. Ozamiz, L. Underwood and M. Weiss. 2005. 'The intrinsic value of mental health. Promoting mental health: Concepts, emerging evidence and practice. Geneva: World Health Organization.

Liang, H. R., H. L. Liang and C. K. Sun. 2016. Coping with negative work experience and work-related family issues: Spirituality as a buffer against emotional exhaustion and work-family conflict. Asian Business Research 1(1): 42.

Madden, T. 2015. Journeys of purpose: A review of literature about work and spirituality. International Journal of Religion \& Spirituality in Society 5(4).

Mayer, C. H. 2012. Der Einfluss von Kultur und Spiritualität auf die Gesundheit, Der Mensch, Zeitschrift für Salutogenese und anthropologische Medizin. Ausgabe Kultur und Gesundheit 44(1):15-21.

Mayer, C. H. and H. A. Barnard. 2015. Balancing the scales of gender and culture in contemporary South Africa. In The psychology of gender and culture, ed. S. Safdar and N. KosakowskaBerezecka, 327-352. New York: Springer.

Mayer, C. H. and L. E. van Zyl. 2013. Perspectives of female leaders on sense of coherence and mental health in an engineering environment. SA Journal of Industrial Psychology/SA Tydskrif vir Bedryfsielkunde 39(2), Art. \#1097, doi.org/10.4102/sajip.v39i2.1097.

Mayer, C. H. and S. Surtee. 2015. The leadership preferences of women leaders working in higher education. Géneros 4(1): 612-636. 
Mayer, C. H., S. Surtee and M. S. May. 2015. The meaningfulness of work for a diverse group of women working in higher education institutions. South African Journal of Higher Education 29(6): 182205.

Miller, D. W. and T. Ewest. 2013. The present state of workplace spirituality: A literature review considering context, theory, and measurement/assessment. Journal of Religious \& Theological Information 12(1-2): 29-54.

Ngunjiri, F. W. 2016. 'I am because we are' - exploring women's leadership under ubuntu worldview. Advances in Developing Human Resources 18(2): 223-242.

Paul, M., A. Dutta and P. Saha. 2016. Improving organizational effectiveness through workplace spirituality and organizational citizenship behaviour: A conceptual review. Globsyn Management Conference 2015 (1): 79.

Pawar, B. S. and B. S. Pawar. 2016. Workplace spirituality and employee well-being: An empirical examination. Employee Relations 38(6): 975-994.

Person, K., M. S. May and C. H Mayer. 2016. The meaning of work for South African women: A phenomenological study. Journal of Psychology in Africa 26(2): 134-140.

Peterson, C. and M. E. P. Seligman, eds. 2004. Character strengths and virtues. Washington: American Psychological Association.

Petchsawang, P. and D. Duchon. 2012. Workplace spirituality, meditation, and work performance. Journal of Management, Spirituality \& Religion 9(2): 189-208.

Porter, T. H. and S. E. Norris. 2013. Workplace spirituality: A best practice toward organizational integrity. In Integrity in organizations: Building the foundations for humanistic management, ed. W. Amann and A. Stachowich-Stanusch, 429-438. Palgrave Macmillan.

Ratner, C. 2002. Subjectivity and objectivity in qualitative methodology. Forum Qualitative Social Research. http://nbn-resolving.de/urn:nbn:de:0114-fqs0203160

Reid, M., D. Roumpi and A. M. O'Leary-Kelly. 2015. Spirited women: The role of spirituality in the work lives of female entrepreneurs in Ghana. Africa Journal of Management 1(3): 264-283.

Rozario, L. 1997. Spirituality in the lives of people with disability and chronic illness: A creative paradigm of wholeness and reconstitution. Disability Rehabilitation 19(10): 427-434.

Rudman, L. A., C. A. Moss-Racusin, J. E. Phelan and S. Nauts. 2012. Status incongruity and backlash effects: Defending the gender hierarchy motivates prejudice against female leaders. Journal of Experimental Social Psychology 48(1): 165-179.

Sandhu, D. 2016. A review of research literature on workplace spirituality. Global Journal for Research Analysis 4(7).

Shahabinasab, A., J. E. Pira, F. Kohansal, S. Golpa and S. Arminpili. 2016. Investigate the effect of spirituality in work on organizational citizenship behavior with the moderating role of organizational commitment. (Case Study: Yasouj University Staff).

Sheep, M. L. 2004. Nailing down gossamer: A valid measure of the person-organization fit of workplace spirituality. Academy of Management Proceedings 1: 1-6.

Snyder, C. R. and S. J. Lopez, eds. 2002. Handbook of positive psychology. New York: Oxford University Press.

Steffen, P. R. 2012. Approaching religiosity/spirituality and health from the eudaimonic perspective. Social and Personality Compass 6(1): 70-82.

Steger, M. F. 2012. Experiencing meaning in life: Optimal functioning at the nexus of well-being. Psychopathology, and spirituality. In The human quest for meaning, ed. P. T. Wong, 165-184. New York: Routledge.

Steger, M. F. and P. Frazier. 2005. Meaning in life: One link in the chain from religiousness to wellbeing. Journal of Counselling Psychology 52(4): 574-582.

Stoltz-Loike, M. 2016. Creating personal and spiritual balance: Another dimension in career 
development. In Connections between spirit and work in career development: New approaches and practical perspectives, ed. D. P. Bloch and L. J. Richmond, 139-162. New York: Routledge.

Terre Blanche, M., K. Durrheim and K. Kelly. 2006. First steps in qualitative data analysis. In Research in practice. Applied methods for the social sciences, ed. M. Terre Blanche, K. Durrheim and D. Painter, 321-344. Cape Town: University of Cape Town.

Tomer, G., S. Xanthakos, S. Kim, M. Rao, L. Book, H. J. Litman and L. N Fishman. 2015. Perceptions of gender equality in work-life balance, salary, promotion, and harassment: Results of the NASPGHAN Task Force Survey. Journal of Pediatric Gastroenterology and Nutrition 60(4): 481-485.

Tracy, S. J. 2010. Qualitative quality: Eight 'big-tent' criteria for excellent qualitative research. Qualitative Inquiry 16(10): 837-851.

Tzouramani, E. and F. Karakas. 2016. Spirituality in management. In Spirituality across disciplines: Research and practice, 273-284. Switzerland: Springer International.

Underwood, L. G. and J. A. Teresi. 2002. The daily spiritual experience scale: Development, theoretical description, reliability, exploratory factor analysis, and preliminary construct validity using healthrelated data. Annual Behavioural Medicine 24(1): 22-33.

Vaismoradi, M., J. Jones, H. Turunen and S. Snelgrove. 2016. Theme development in qualitative content analysis and thematic analysis. Journal of Nursing Education and Practice 6(5): 100.

Van Dierendonck, D. and K. Mohan. 2006. Some thoughts on spirituality and eudaimonic well-being. Mental Health, Religion and Culture 9(3): 227-238.

Van Manen, M. 2007. Phenomenology of practice. Phenomenology \& Practice 1(1): 11-30.

Walsh, K., S. S. Fleming and C. A. Enz. 2016. Give and you shall receive: Investing in the careers of women professionals. Cornell University School of Hotel Administration. The scholarly commons. http://scholarship.sha.cornell.edu/cgi/viewcontent.cgi?article=1880\&context=articles

Wissing, M., J. Potgieter, T. Guse, T. Khumalo and L. Nel. (Eds.). 2014. Towards flourishing: Contextualising positive psychology. Pretoria: Van Schaik.

Woodley, X. M. and M. Lockard. 2016. Womanism and snowball sampling: Engaging marginalized populations in holistic research. The Qualitative Report 21(2): 321.

Yin, R. K. 2009. Case study research: Design and methods. 4th edition. London: Sage. 